Article

\title{
Preparation and Characterization of
} Tetra-Imidazolium Hydroxide Polyphenylene Membranes via Nickel Catalyzed C-C Coupling Polymerization

\author{
Hohyoun Jang ${ }^{1}$, Soonho Lee ${ }^{1}$, Jaeseong Ha ${ }^{1}$, Kunyoung Choi ${ }^{1}$, Taewook Ryu ${ }^{1}$, \\ Kyunghwan Kim ${ }^{1}$, Heung-Seok Jeon ${ }^{2}$ and Whangi Kim ${ }^{1, *}$ \\ 1 Department of Applied Chemistry, Konkuk University, Chungju 380-701, Korea; figfight@hanmail.net (H.J.); \\ loveknotsh@hanmail.net (S.L.); wotjd9608@naver.com (J.H.); Korea_355@naver.com (K.C.); \\ gundam0924@naver.com (T.R.); kkh1148@naver.com (K.K.) \\ 2 Department of Computer Engineering, Konkuk University, Chungju 380-701, Korea; hsjeon@kku.ac.kr \\ * Correspondence: wgkim@kku.ac.kr; Tel.: +82-43-840-3579
}

Academic Editor: Vladimir Gurau

Received: 16 December 2015; Accepted: 28 March 2016; Published: 6 April 2016

\begin{abstract}
Imidazolium hydroxide anion exchange membranes functionalized with conjugated tetraphenylethylene moieties were synthesized via $\mathrm{Ni}(0)$ catalyzed polymerization by sequential chloromethylation, substitution with imidazoliums and ion exchange. Moreover, with their pendant benzoyl groups the copolymers showed high molecular weight, durability, thermo-oxidative stability, high solubility in polar aprotic solvents and strong chemical and thermal stability in comparison to alkyl quaternary ammonium-functionalized polymers. The proposed polymer membranes, without ether linkages, demonstrated improved performance in ion exchange capacity, water uptake, ion conductivity, and thermal stability. The polymer membranes were studied by ${ }^{1} \mathrm{H}-\mathrm{NMR}$ (Nuclear Magnetic Resonance) spectroscopy, thermogravimetric analysis, water uptake, ion exchange capacity and ion conductivity. Surface morphologies were assessed by atomic force microscope (AFM). The synthesized polymers may have applications as fuel cell membranes because of their excellent ion conductivity.
\end{abstract}

Keywords: imidazolium; nickel catalyst; polyphenylene; anion exchange membrane; alkaline fuel cell

\section{Introduction}

Fuel cells are eco-friendly power sources having high energy density. Compared to other types of polymer electrolyte membranes, perfluorosulfonic acid polymers are more effective $[1,2]$ but in the same time they tend to be expensive. To overcome these demerits, alkaline anion exchange membranes (AAEMs) are being developed [3-5]. They employ electrode catalysts ( $\mathrm{Fe} / \mathrm{Co} / \mathrm{Ni} / \mathrm{Ag}$ ) and show better cathode kinetics than other fuel cells [6-9]. Quaternary ammonium functionalized anion exchange membranes (QAAEM) have been developed and many researchers have revealed that the QAAEMs possess low conductivity and poor stability [10-15]. The common possible degradation pathways of quaternary ammonium species associated with $\mathrm{OH}^{-}$ions include Hoffman (E2) elimination, direct nucleophilic substitution (SN2) and also ylide formation [3,4,16-18]. Recently, imidazolium-based AEMs have stood out in this aspect. These membranes have five-membered heterocyclic rings and conjugated imidazolium cation structures, which are expected to display good stability under alkaline conditions [19-21]. Therefore, our aim was to prepare AEM materials with a resonance stabilized cationic group, like an imidazolium cation. The membranes containing conjugated imidazole rings are chemically more stable at high $\mathrm{pH}$ than ones with quaternary ammonium species, showing no 
apparent loss of ionic conductivity $[3,22]$. We synthesized polymers without ethers linkage in the polymer main chain by carbon-carbon coupling reactions because polymer ether linkages are easily degraded by nucleophiles. There are three kinds of method to accomplish this: the Ni/Zn method, the superacid method, and the Diels-Alder method. Among them the Ni/Zn method is easy to use to obtain high molecular weights and useful to form a variety of monomer structures [23-28].

This work reports the fabrication of a series of anion exchange membranes containing poly(phenylene) units with four imidazolium functionalized ionic groups on the main polymer chain. The membranes were synthesized by nickel-catalyzed polymerization, chloromethylation using chloro methyl methyl ether, anhydrous zinc chloride as a Lewis acid catalyst and treatment with 1-methylimidazole. The tetraphenylene monomer consisted of a 4:6 ratio of cis and trans forms. With this conjugated cis/trans isomer basis it has a non-planar conformation containing the peripheral four aromatic rings. The alkaline tetra-imidazolium functionalized membranes were characterized by ${ }^{1}$ H-NMR (Nuclear Magnetic Resonance) spectroscopy, thermogravimetric analysis, water uptake, ion exchange capacity assessment and by the investigation of atomic force microscopic (AFM) images.

\section{Experimental Section}

\subsection{Materials}

2-5-Dichloro- $p$-xylene, potassium permanganate, pyridine, thionyl chloride, benzene, chloromethyl methyl ether, 1-methylimidazole, zinc chloride, potassium hydroxide, nickel bromide, triphenylphosphine, zinc powder, aluminum chloride and sulfuric acid were purchased from TCI (Tokyo, Japan), Sigma-Aldrich (St. Louis, MO, USA) and Alfa Aesar (Lancashire, UK). Nickel bromide, zinc powder, and triphenylphosphine were stored under nitrogen in a glove box. $N, N$-dimethylacetamide (DMAc) was dried over calcium hydride and distilled prior to use. Commercial solvents, dimethylsulfoxide (DMSO), 1,1,2,2,-tetrachloroethane, carbon disulfide, ethyl acetate, dichloromethane, methanol, acetone, ethanol, hexane and distilled water, were used without further purification. Bis(4-chlorophenyl)-1,2diphenylethylene (BCD) was synthesized as described in [29].

\subsection{Preparation of 1,4-Dichloro-2,5-Dibenzoylbenzene (PBP)}

A mixture of 2,5-dichloro- $p$-xylene ( $2.6 \mathrm{~g}, 11.5 \mathrm{mmol})$, potassium permanganate $(13.6 \mathrm{~g}, 88.5 \mathrm{mmol})$, and pyridine $(40.5 \mathrm{~mL}, 512 \mathrm{mmol})$ in distilled water $(12.5 \mathrm{~mL})$ was placed in a $250 \mathrm{~mL}$ round bottom flask. The mixture was stirred for $12 \mathrm{~h}$ at a temperature of $100^{\circ} \mathrm{C}$. The reaction mixture was cooled to room temperature and filtered. The filtrate was evaporated to remove pyridine and water. The solid was dissolved in water and acidified with hydrochloric acid to a $\mathrm{pH}$ of 1 . The resulting white solid was filtered and dried in an oven at $60^{\circ} \mathrm{C}$. Dichloroterephthalic acid $(2.15 \mathrm{~g}, 9.25 \mathrm{mmol})$ was stirred at reflux condition for $24 \mathrm{~h}$ with thionyl chloride $(7.5 \mathrm{~mL}, 9.75 \mathrm{mmol})$ and pyridine $(0.09 \mathrm{~mL}, 0.9 \mathrm{mmol})$. The solution was evaporated and a yellow solid obtained. Immediately, the yellow solid was dissolved in carbon disulfide and added dropwise into benzene $(2.45 \mathrm{~mL}, 27.75 \mathrm{mmol})$, and aluminum chloride $(6.17 \mathrm{~g}, 46.25 \mathrm{mmol})$ in carbon disulfide $(50 \mathrm{~mL})$ over $30 \mathrm{~min}$. The mixture was stirred at $40{ }^{\circ} \mathrm{C}$ for $24 \mathrm{~h}$ and the residue was poured into ice water with hydrochloric acid. The product was filtered and washed twice with water and also recrystallized using ethanol before drying in an oven at $60{ }^{\circ} \mathrm{C}$ [30].

\subsection{Preparation of Poly(tetraphenylethylene)-co-(dibenzoylphenylene) (PTPEDBP)}

The polymerization was conducted in a $100 \mathrm{~mL}$ three-neck flask containing nickel bromide $(0.11 \mathrm{~g}$, $0.51 \mathrm{mmol})$, zinc powder $(2 \mathrm{~g}, 30.71 \mathrm{mmol})$, and triphenylphosphine $(1.07 \mathrm{~g}, 4.09 \mathrm{mmol})$ with a nitrogen inlet. In another one-neck round-flask, bis(4-chlorophenyl)-1,2-diphenylethylene $(0.45 \mathrm{~g}, 1.12 \mathrm{mmol})$ and 1,4-dichloro-2,5-dibenzoylbenzene $(1.6 \mathrm{~g}, 4.48 \mathrm{mmol})$ were taken. The mixture of catalysts and monomers were prepared in glove box under a nitrogen atmosphere. DMAc was added via syringe into the catalyst flask and stirred at $80^{\circ} \mathrm{C}$ for $10 \mathrm{~min}$. The monomers were dissolved in DMAc and injected slowly by syringe into the catalyst flask, whereby the solution of catalyst changed color to 
deep red. The reaction was allowed to proceed for $24 \mathrm{~h}$ at $100{ }^{\circ} \mathrm{C}$. After that the polymer was poured into water with $30 \%$ hydrochloric acid. The resulting bright yellow solid was filtered and washed with methanol and water. After drying in an oven at $60^{\circ} \mathrm{C}$, the polymer was dissolved in DMAc and reprecipitated in $10 \% \mathrm{HCl}$ aqueous solution before drying in an oven at $60^{\circ} \mathrm{C}$.

\subsection{Preparation of Chloromethylated Polymer (PTPEDBP-Cl)}

PTPEDBP-Cl was prepared by the chloromethylation of PTPEDBP $(1.0 \mathrm{~g}, 1.84 \mathrm{mmol})$ in 1,1,2,2-tetrachloroethane $(15.0 \mathrm{~mL})$ in a $100 \mathrm{~mL}$ three neck round-bottom flask, fitted with a condenser, a nitrogen inlet/outlet and a magnetic stirrer. Zinc chloride $(0.25 \mathrm{~g}, 1.84 \mathrm{mmol})$ was added at room temperature and chloro methyl methyl ether $(3.65 \mathrm{~mL})$ was then added dropwise. The reaction mixture was stirred for $12 \mathrm{~h}$ at room temperature. It was precipitated using mixture of methanol and water (50:50) and repeatedly washed with methanol and deionized water, individually. The light brown polymer was collected by filtration and dried in a vacuum oven for $24 \mathrm{~h}$ at $80^{\circ} \mathrm{C}$.

\subsection{Preparation of Tetra-Imidazolium Chloride Polymer (PTPEDBP-I/Cl)}

PTPEDBP-I/Cl was prepared from a solution of PTPEDBP-Cl $(0.5 \mathrm{~g}, 0.81 \mathrm{mmol})$ in DMAc $(8.0 \mathrm{~mL})$. Firstly, 1-methylimidazole $(0.81 \mathrm{~mL}, 7.14 \mathrm{mmol})$ was added dropwise. The mixture was stirred for $24 \mathrm{~h}$ at $55^{\circ} \mathrm{C}$, cooled to room temperature and decanted into ethyl acetate for precipitation. The light yellow solid was collected by filtration and repeatedly washed with ethyl acetate to remove any remaining 1-methylimidazole. The solid polymer was dried in a vacuum oven at $80^{\circ} \mathrm{C}$ for $24 \mathrm{~h}$.

\subsection{Preparation of Tetra-Imidazolium Hydroxide Polymer (PTPEDBP-I/OH)}

PTPEDBP-I/OH was prepared from $10 \mathrm{wt} \%$ PTPEDBP-I/Cl dissolved in dimethylsulfoxide. The membrane was prepared by casting this solution to $25 \mu \mathrm{m}$ thickness on a flat glass plate $(5 \mathrm{~cm} \times 5 \mathrm{~cm})[4,10]$. The membrane's thickness was controlled by using a polymer $\mathrm{wt} \%$ solution. It was then dried at $80^{\circ} \mathrm{C}$ for $24 \mathrm{~h}$ in a vacuum oven. The chloride anions $\left(\mathrm{Cl}^{-}\right)$were converted to $\mathrm{OH}^{-}$by immersing the membrane in $1.0 \mathrm{M} \mathrm{KOH}$ solution for $48 \mathrm{~h}$. It was then repeatedly washed with deionized water until the $\mathrm{pH}$ of the residual water was neutral.

\subsection{Characterization of Membranes}

The copolymer structure was confirmed by ${ }^{1} \mathrm{H}-\mathrm{NMR}$ spectra, which were recorded on a DRX (400 MHz) spectrometer (Bruker, Billerica, $\mathrm{MA}, \mathrm{USA}$ ) using $\mathrm{CDCl}_{3}$ and deuterated dimethylsulfoxide $\left(\right.$ DMSO- $\mathrm{d}_{6}$ ) solvents and tetramethylsilane (TMS) as an internal standard. Thermogravimetric analysis was performed using a TGA-7 analyzer (Perkin-Elmer, Waltham, MA, USA). Water uptake, the percentage mass change of the dry membrane was assessed from the mass difference of the membrane vacuum dried at $100{ }^{\circ} \mathrm{C}$ for $24 \mathrm{~h}$ before and after immersion in deionized water at $80^{\circ} \mathrm{C}$ for $24 \mathrm{~h}$. The wet membrane was wiped dry before weighing. Membrane swelling degree was calculated as the percentage length change of each dry membrane after immersion in water at $80^{\circ} \mathrm{C}$ for $24 \mathrm{~h}$. Membrane ion exchange capacity was determined by back titration. A membrane in the $\mathrm{OH}^{-}$form was immersed in a standard hydrochloric acid solution $(0.1 \mathrm{M}, 30.0 \mathrm{~mL})$ for $48 \mathrm{~h}$. The solution was then titrated with a standard solution of potassium hydroxide $(0.1 \mathrm{M})$ using phenolphthalein as an indicator. The membrane was washed and immersed in deionized water for $24 \mathrm{~h}$ to remove any remaining $\mathrm{HCl}$ and then dried under vacuum at $60{ }^{\circ} \mathrm{C}$ for $24 \mathrm{~h}$. Its dry mass was measured. The membrane's ion exchange capacity (IEC $/ \mathrm{mmol} \mathrm{g}^{-1}$ ) was calculated as the ratio of the amount of protons lost from the $\mathrm{HCl}$ solution determined by titration to the mass of dry membrane. Ionic conductivities in hydroxide $\left(\mathrm{OH}^{-}\right)$form of the fully hydrated membranes were determined from their resistance measured by electrochemical impedance spectroscopy using a membrane testing system (MTS-740, Scribner Associates Inc., Southern Pines, NC, USA) with an impedance analysis interface (PSM 1735, Newton's 4th Ltd., Leicester, UK) at $80^{\circ} \mathrm{C}$ under $100 \%$ relative humidity. Evaluation of ionic conductivity under fully hydrated conditions was performed with the cell immersed in deionized 
water at room temperature. All the prepared samples were equilibrated in pure water for at least $24 \mathrm{~h}$ prior to conductivity estimation. The samples were brought into equilibrium with the given temperature for at least $30 \mathrm{~min}$ before any measurement. Assessment was conducted under open circuit conditions by applying a small alternating voltage $(10 \mathrm{mV})$ with frequency varied from $1 \times 10^{5}$ to $1 \mathrm{~Hz}$. Ion conductivity was calculated as:

$$
\sigma=\mathrm{L} /\left(\mathrm{R}_{\mathrm{mem}} \times \mathrm{A}\right)
$$

where $\mathrm{L}$ is the membrane thickness in $\mathrm{cm}$, $\mathrm{A}$ is the electrode area in $\mathrm{cm}^{2}$, and $\mathrm{R}_{\mathrm{mem}}$ is ohmic resistance measured by four-point probe alternating current electrochemical impedance spectroscopy. The surface morphologies of the anionic polymer membranes were observed by atomic force microscope (AFM). Tapping mode atomic force microscopic observations were performed with a Nanoscope (R) IIIA device (Digital Instrument, Milano, Italy), using microfabricated cantilevers with an amplitude set point $0.7785 \mathrm{~V}$. All samples were cast on a flat glass plates and heated at $60{ }^{\circ} \mathrm{C}(3 \mathrm{~h}), 80^{\circ} \mathrm{C}(3 \mathrm{~h}), 100{ }^{\circ} \mathrm{C}$ $(3 \mathrm{~h})$, and $120^{\circ} \mathrm{C}$ for $1 \mathrm{~h}$ to form around $25 \mu \mathrm{m}$. The resulting films were allowed to stand under $100 \%$ relative humidity at room temperature prior to investigation. The chemical stability of the alkaline polymer membranes were assessed by measuring the weight change in each day after immersion the sample in $1.0 \mathrm{M} \mathrm{KOH}$ solution at $60^{\circ} \mathrm{C}$.

\section{Results and Discussion}

\subsection{Preparation of Polymers}

The polymers were synthesized via nickel-catalyzed carbon-carbon coupling polymerization of bis(4-chlorophenyl)-1,2-diphenylethylene and 1,4-dichloro-2,5-dibenzoylbenzene (Figure 1). Sulfonation was then performed to introduce sulfonic acid groups in the polymer. The number of sulfonic acid groups was controlled by varying the mole ratio of $B C D$ monomer. A series of sulfonated polymers were prepared by controlling the mole ratios of BCD at $10 \%, 15 \%$ and $20 \%$. Figure 2 shows the chemical structure of PTPEDBP polymer by ${ }^{1} \mathrm{H}-\mathrm{NMR}$. The protons of phenyl groups appeared at $6.76-8.00 \mathrm{ppm}$.
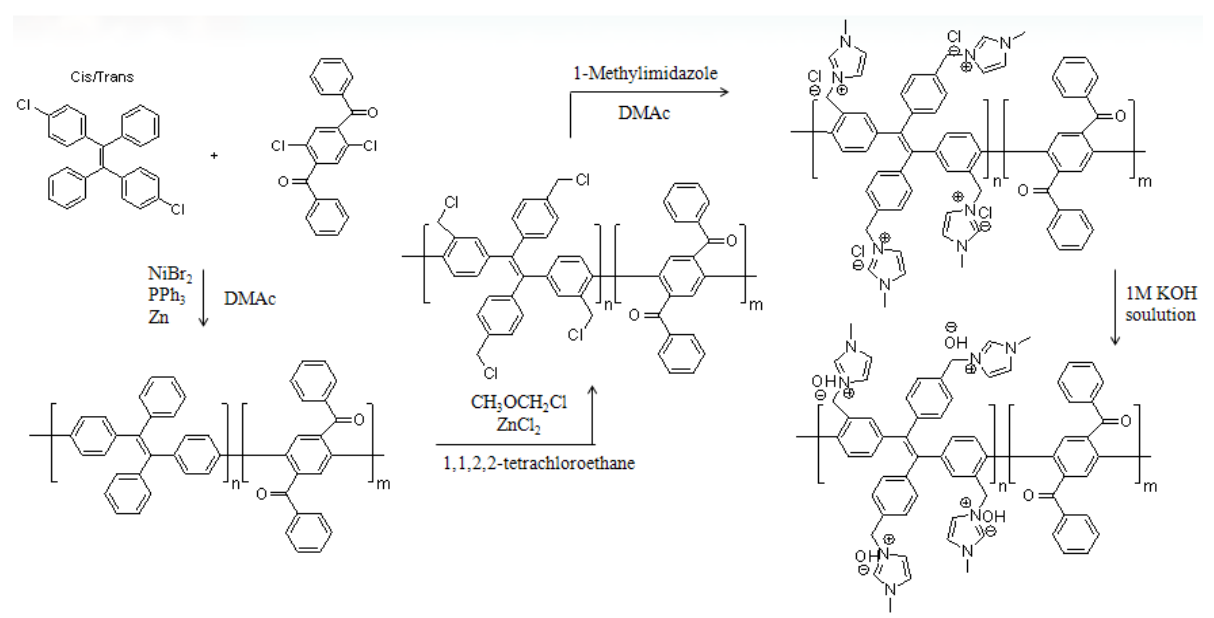

Figure 1. Synthesis of tetra-imidazolium polymer. 


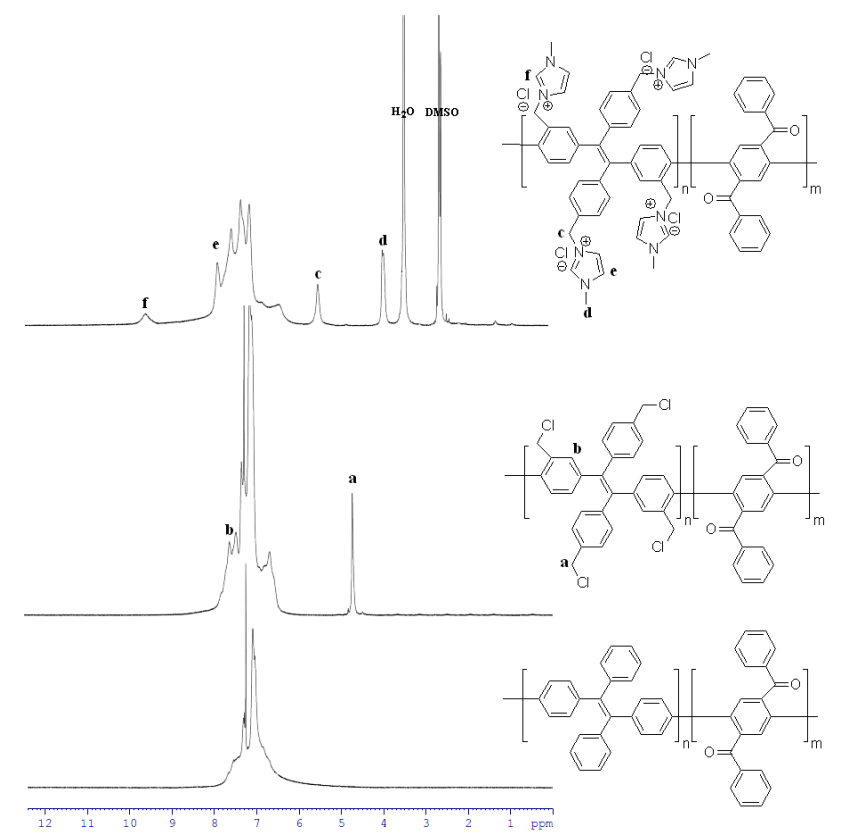

Figure 2. ${ }^{1} \mathrm{H}-\mathrm{NMR}$ (Nuclear Magnetic Resonance) of poly(tetraphenylethylene)-co(dibenzoylphenylene) (PTPEDBP), chloromethylated polymer (PTPEDBP-Cl) and tetra-imidazolium chloride polymer (PTPEDBP-I/Cl).

Chloromethylated polyphenylene (PTPEDBP-Cl) was prepared by Friedel-Crafts reaction with chloromethyl methyl ether and a Lewis acid catalyst, $\mathrm{ZnCl}_{2}$ (Figure 1). Reaction time, the ratio of chloromethyl methyl ether and amount of $\mathrm{ZnCl}_{2}$ are important to control the molecular weight of the resulting polymer. A 1:30 mole ratio of $\mathrm{ZnCl}_{2}$ and chloro methyl methyl ether (CMME) represents effective chloromethylation conditions to avoid any degradation of the polymer and achieve $100 \%$ substitution. The PTPEDBP-Cl structure was confirmed by ${ }^{1} \mathrm{H}-\mathrm{NMR}$. The methylene protons of the chloromethyl groups appeared at $4.5 \mathrm{ppm}$ (Figure 2). Chloromethylation yield $(100 \%)$ was estimated from the integral ratio of methylene protons to the total phenyl protons at $6.72-7.78 \mathrm{ppm}$.

PTPEDBP-I/Cl was prepared using 1-methylimidazole in 1,1,2,2-tetrachloroethane at $70{ }^{\circ} \mathrm{C}$ for $24 \mathrm{~h}$ (Figure 1). Conversion of chloromethyl groups to imidazolium was achieved by controlling the molar ratio of PTPEDBP-Cl and 1-methylimidazole. It was observed that the 1:12.5 mole ratio of PTPEDBP-Cl and 1-methylimidazole gave imidazolium chloride polymer without any polymer backbone degradation, whose structure was identified by the characteristic downfield peak at 5.41, $9.48 \mathrm{ppm}$ (Figure 2) which indicated the imidazolium cation-essentially an electron withdrawing group [31]. NMR data showed that 100\% conversion to imidazolium groups occurred. This membrane's thickness was controlled by using polymer wt $\%$ solution to a thickness of $25 \mu \mathrm{m}[4,32]$. Usually, membranes thicker than $50 \mu \mathrm{m}$ show poor uptake of hydroxide ions.

\subsection{Properties of Anion Exchange Membrane}

Thermal stability is required for anion exchange membranes at high temperatures to control thermodynamic voltage losses during the membranes' use in fuel cells [33]. The thermooxidative stabilities of membranes were investigated by themogravimetric analysis. Figure 3 reveals that PTPEDBP is thermally stable up to $520^{\circ} \mathrm{C}$ in air. The weight loss of PTPEDBP-Cl at around $200-400{ }^{\circ} \mathrm{C}$ corresponds to the decomposition of chloromethyl groups. The weight loss of PTPEDBP-I/OH shown at $250{ }^{\circ} \mathrm{C}$ probably corresponds to the decomposition of the imidazolium cation. However, membranes bearing imidazolium cations were more thermally stable than those containing ammonium groups in the anion exchange membrane [33] because of the higher decomposition temperature of the imidazolium groups $[3,31]$. 


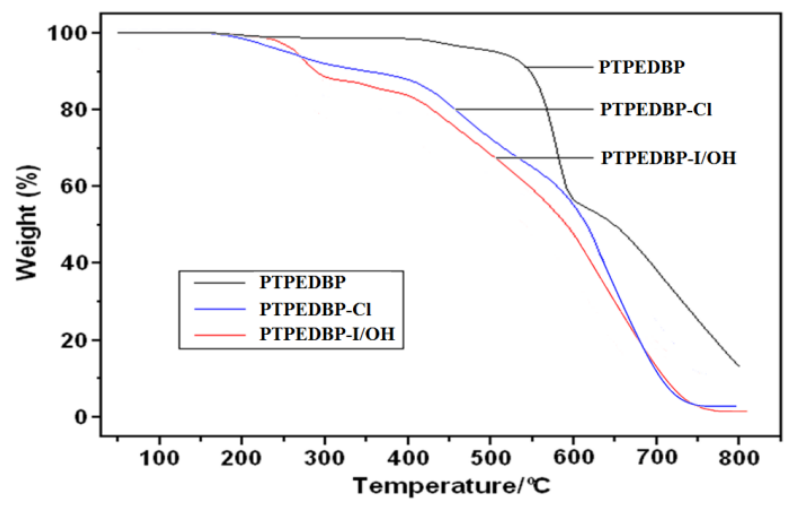

Figure 3. Thermooxidative stabilities of poly(tetraphenylethylene)-co-(dibenzoylphenylene) (PTPEDBP), chloromethylated polymer (PTPEDBP-Cl), tetra-imidazolium hydroxide polymer (PTPEDBP-I/OH).

Membranes suitable for alkaline fuel cells require sufficient imidazolium groups to provide ionic conductivity while maintaining mechanical integrity. The ion exchange capacities of the PTPEDBP-I/OH membranes increased as 1.14, 1.67, and $2.08 \mathrm{mmol} \mathrm{g}^{-1}$ with the increasing numbers of imidazolium hydroxide groups-the theoretical and the experimental (titrated) capacities were in reasonably good agreement (Table 1). Membranes' water uptakes varied from $12.7 \%$ to $31.2 \%$ at $30{ }^{\circ} \mathrm{C}$ and from $25.4 \%$ to $64.5 \%$ at $80{ }^{\circ} \mathrm{C}$ with increasing numbers of imidazolium hydroxide groups (Table 1 ).

Table 1. Properties of tetra-imidazolium hydroxide polymer (PTPEDBP-I/OH) membranes.

\begin{tabular}{ccccc}
\hline Polymer & $\begin{array}{c}\text { Theoretical IEC } \\
\text { (meq./g) }\end{array}$ & $\begin{array}{c}\text { Titrated IEC } \\
\text { (meq./g) }\end{array}$ & $\begin{array}{c}\text { Water Uptake } \mathbf{1}^{\mathbf{1}} \\
\mathbf{( \% )}\end{array}$ & $\begin{array}{c}\text { Proton Conductivity }^{\mathbf{2}} \\
\text { (mS/cm) }\end{array}$ \\
\hline PTPEDBP-I/OH 10 & 1.32 & 1.14 & 25.4 & 16.8 \\
PTPEDBP-I/OH 15 & 1.78 & 1.67 & 38.4 & 24.5 \\
PTPEDBP-I/OH 20 & 2.24 & 2.08 & 64.5 & 30.5 \\
\hline
\end{tabular}

${ }^{1}$ Water uptake at $80{ }^{\circ} \mathrm{C} ;{ }^{2}$ Ion conductivity at $80{ }^{\circ} \mathrm{C}$ under $100 \%$ relative humidity; IEC, ion exchange capacity.

In Figure 4 shows increase of water uptake for the PTPEDBP-I/OH membranes as IEC increases. The hydrophilic properties of the membranes become better with increasing IEC values. Therefore, the polyphenylene membranes become more hydrophilic and absorb more water with the increases of IEC from 1.14 to 2.08 . Water uptake is low like in other imidazolium-based systems $\left(24.76 \%\right.$ at $60{ }^{\circ} \mathrm{C}$ and $<31 \%)[3,34]$.

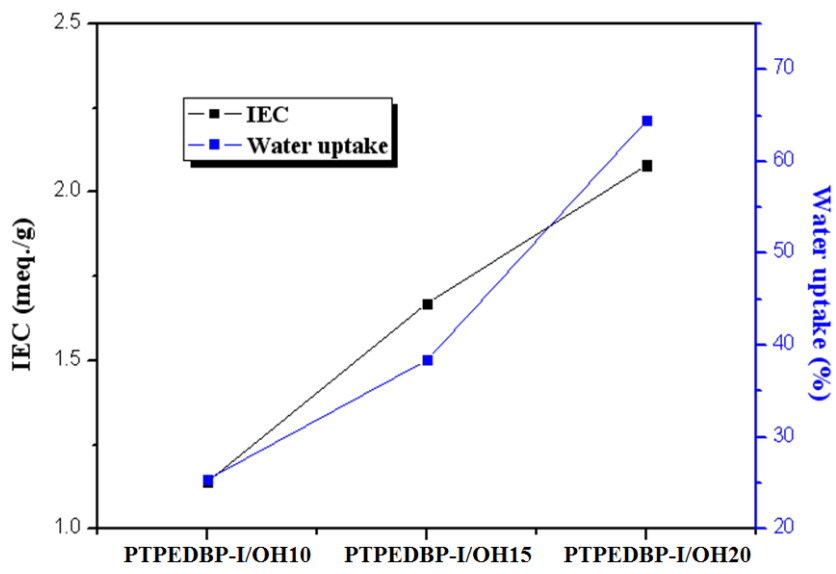

Figure 4. Ion exchange capacity (IEC) and water uptake of tetra-imidazolium hydroxide polymer (PTPEDBP-I/OH) membranes at $30^{\circ} \mathrm{C}$. 
Compared to the ammonium hydroxide membranes of the IEC values of 1.88 and $2.54 \mathrm{mmol} \mathrm{g}^{-1}$ and water uptakes $95 \%$ and $160 \%$ ) [10], our imidazolium-based polyphenylene membrane showed very low water uptakes. This is possibly due to the presence of conjugated imidazole rings which weakens the interaction with water molecules. In Table 1, the imidazolium-containing membranes showed less swelling than other reported anion exchange membranes containing ammonium groups (26.8\%-58.8\%) [32], demonstrating their high dimensional stability due to both the resonance stabilized conjugated imidazolium cations and rigid backbone. Ion conductivities of 16.8 to $30.5 \mathrm{mS} \mathrm{cm}^{-1}$ were observed at $80{ }^{\circ} \mathrm{C}$ and $100 \%$ relative humidity. Conductivity values increased as ion exchange capacity and temperatures increased (Figure 5 and Table 1).

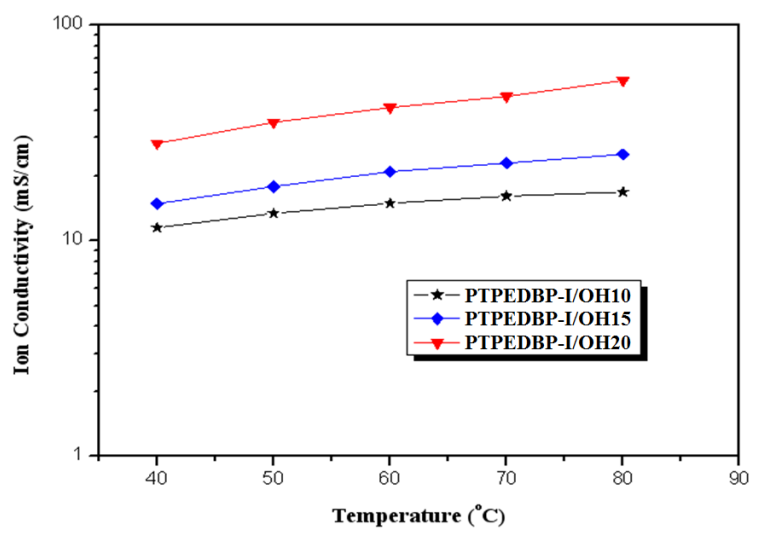

Figure 5. Ion conductivities of the fully tetra-imidazolium hydroxide polymer (PTPEDBP-I/OH) membranes at $40-80{ }^{\circ} \mathrm{C}$ and $100 \%$ relative humidity.

At higher temperatures, the membranes showed high water affinity and led to faster migration of ions and high ionic conductivity [3]. The developed AEMs (Tokuyama Co., Tokyo, Japan) are hydrocarbon polymers which consist of hydrocarbon main chains and quaternary ammonium salts. The $\mathrm{OH}^{-}$conductivities of Tokuyama membrane are around $38-42 \mathrm{mS} \mathrm{cm}^{-1}$, and our membranes shows a little low value of $31 \mathrm{mS} \mathrm{cm}^{-1}$ [35]. The PTPEDBP-I/OH membranes show low ion conductivities, despite their higher ion exchange capacities like typical hydrocarbon membranes (10-22 $\mathrm{mS} \mathrm{cm}^{-1}$ and 18-46 mS cm $\mathrm{cm}^{-1}$ ) [36]. This was possibly due to low water absorption caused by resonance effects. The polymers' surface morphologies were assessed on a $1 \mu \mathrm{m} \times 1 \mu \mathrm{m}$ scale by atomic force microscopy in tapping mode under ambient conditions (Figure 6).
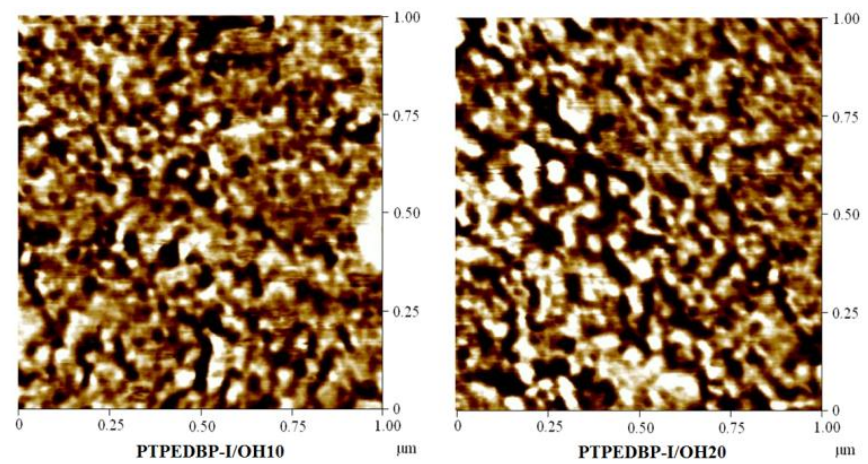

Figure 6. Atomic force microscopy images of tetra-imidazolium hydroxide polymer membranes PTPEDBP-I/OH 10 and PTPEDBP-I/OH 20.

Several worm-shaped domains are better observed in PTPEDBP-I/OH. The swollen hydrophilic domains were assumed to be more connected to the bulk membrane, rather remaining isolated from 
each other. The hydrophilic domain with microstructure is distinctive with disordered ionic channels. The membrane provided the required ionic conductivity for fuel cell applications owing to the larger number of interconnects of the hydrophilic domains in the disordered morphology [31]. Anion exchange membranes in alkaline fuel cells require chemical stability against nucleophilic attack by $\mathrm{OH}^{-}$ions. The PTPEDBP-I/OH membranes' stabilities were investigated in $1.0 \mathrm{M} \mathrm{KOH}$ at $60{ }^{\circ} \mathrm{C}$ over 5 days $[3,9,31]$. Ion conductivity was measured each day after free $\mathrm{KOH}$ had been removed through washing in deionized water.

The membranes showed relatively better chemical stability (Figure 7) than the quaternary ammonium functionalized polymers [36]; the quaternary ammonium polymers suffer from nucleophilic substitution or elimination reactions [4,35], The strong chemical stability aspect of the imidazolium hydroxide polymers is largely affected by the steric hindrance that demonstrates the good competing deprotonation reaction [37] and the presence of conjugated imidazolium cation that could reduce the SN2 substitution and Hofmann (E2) elimination reactions by the aggressive hydroxide nucleophile [3,35]. Overall, the imidazolium functionalized polycarbonate anion exchange membranes are stable in alkaline conditions.

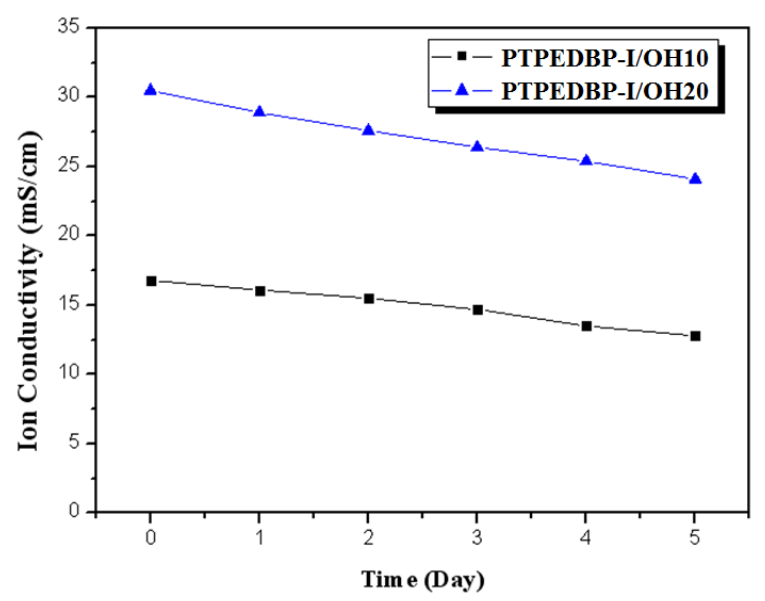

Figure 7. The chemical stability of tetra-imidazolium hydroxide polymer membranes PTPEDBP-I/OH 10 and PTPEDBP-I/OH 20 after immersion in $1.0 \mathrm{M} \mathrm{KOH}$ solution at $60^{\circ} \mathrm{C}$ : ion conductivity at $80{ }^{\circ} \mathrm{C}$ and $100 \%$ relative humidity.

\section{Conclusions}

A series of anion conductive membranes were synthesized by successive chloromethylation, substitution with 1-methylimidazole and ion exchange reactions of bisphenol polycarbonate. Chloromethylation was important in giving quantitative imidazolium substitution and also the subsequent ion exchange reactions. The PTPEDBP-I/OH membranes showed high ionic conductivity $16.8-30.5 \mathrm{mS} \mathrm{cm}^{-1}$ at $80{ }^{\circ} \mathrm{C}$ and $100 \%$ relative humidity. The prepared AEMs bearing imidazolium cation are flexible and show enough good dimensional stability for use as novel potential alkaline fuel cell material candidates. Additionally, alkaline imidazolium membranes exhibit good stability in alkaline conditions that could overcome the known limitations of quaternary ammonium hydroxide polymers. Therefore, the imidazolium-functionalized membranes can contribute to improvements of fuel cell performance because they show relatively better conductivity and chemical stability than ammonium anion membranes, and similar results compared to imidazolium anion membranes.

Acknowledgments: This work was supported by the Human Resource Training Program for Regional Innovation and Creativity through the Ministry of Education and National Research Foundation of Korea (NRF-2014H1C1A1066447) and Basic Science Research Program through the National Research Foundation of Korea (NRF) funded by the Ministry of Education, Science and Technology (2011-0006535). 
Author Contributions: Hohyoun Jang and Soonho Lee conceived and designed the experiments; Hohyoun Jang, Jaeseong Ha, and Kunyoung Choi performed the experiments; Taewook Ryu and Kyungwhan Kim analyzed the data; Heungseok Jeon contributed reagents/materials/analysis tools; Whangi Kim wrote the paper.

Conflicts of Interest: The authors declare no conflict of interest.

\section{References}

1. Vogel, C.; Komber, H.; Quetschke, A.; Butwilowski, W.; Potschke, A.; Schlenstedt, K.; Haack, J.M. Side-chain sulfonated random and multiblock poly(ether sulfone)s for PEM applications. React. Funct. Polym. 2011, 71, 828-842. [CrossRef]

2. Stoica, D.; Ogier, L.; Akrour, L.; Alloin, F.; Fauvarque, J.F. Anionic membrane based on polyepichlorhydrin matrix for alkaline fuel cell: Synthesis, physical and electrochemical properties. Electrochim. Acta 2007, 53, 1596-1603. [CrossRef]

3. Lin, B.; Qiu, L.B.; Peng, Y.; Yan, F. Alkaline Stable Imidazolium-based Ionomers Containing Poly(arylene ether sulfone) Side Chains for Alkaline Anion Exchange Membranes. Macromolecules 2011, 44, 9642-9649. [CrossRef]

4. Tanaka, M.; Fukasawa, K.; Nishino, E.; Yamaguchi, S.; Yamada, K.; Tanaka, H.; Bae, B.; Miyatake, K.; Watanabe, M. Anion Conductive Block Poly(arylene ether)s: Synthesis, Properties, and Application in Alkaline Fuel Cells. J. Am. Chem. Soc. 2011, 133, 10646-10654. [CrossRef] [PubMed]

5. Chempath, S.; Einsla, B.R.; Pratt, L.R.; Macomber, C.S.; Boncella, J.M.; Rau, J.A.; Pivovar, B.S. Mechanism of Tetraalkylammonium Headgroup Degradation in Alkaline Fuel Cell Membranes. J. Phys. Chem. C 2008, 112, 3179-3182. [CrossRef]

6. Wang, G.; Weng, Y.; Zhao, J.; Chu, D.; Xie, D.; Chen, R. Developing a novel alkaline anion exchange membrane derived from poly (ether-imide) for improved ionic conductivity. Polym. Adv. Technol. 2010, 21, 554-560. [CrossRef]

7. Dao, P.T.; Jing, P.; Shan, F.L.; Lin, Z.; Jun, T.L. Alkaline polymer electrolyte fuel cells: Principle, challenges, and recent progress. Sci. China Chem. 2010, 53, 357-364.

8. Switzer, E.E.; Olson, T.S.; Datye, A.K.; Atanassov, P.; Hibbs, M.R.; Fujimoto, C.; Cornelius, C.J. Novel $\mathrm{KOH}$-free anion exchange membrane fuel cell: Performance comparison of alternative anion-exchange ionomers in catalyst ink. Electochim. Acta 2010, 55, 3404-3408. [CrossRef]

9. Wang, G.; Weng, Y.; Chu, D.; Chen, R.; Xie, D. Developing a polysulfone-based alkaline anion exchange membrane for improved ionic conductivity. J. Memb. Sci. 2009, 332, 63-68. [CrossRef]

10. Tanaka, M.; Koike, M.; Miyatake, M.; Watanabe, M. Synthesis and properties of anion conductive ionomers containing fluorenyl groups for alkaline fuel cell applications. Polym. Chem. 2011, 2, 99-106. [CrossRef]

11. Vega, J.A.; Chartier, C.; Mustain, W.E. Effect of hydroxide and carbonate alkaline media on anion exchange membranes. J. Power Sources 2010, 195, 7176-7180. [CrossRef]

12. Zhou, J.; Unlu, M.; Vega, J.A.; Kohl, P.A. Anionic polysulfone ionomers and membranes containing fluorenyl groups for anionic fuel cells. J. Power Sources 2009, 190, 285-292. [CrossRef]

13. Yan, J.; Hickner, M.A. Polysulfone ionomers and membranes containing fluorenyl groups for anionic fuel cells. Macromolecules 2010, 43, 2349-2356. [CrossRef]

14. Vinodh, R.; Ilakkiya, A.; Elamathi, S.; Sangeetha, D. A novel anion exchange membrane from polystyrene (ethylenebutylene) polystyrene: Synthesis and characterization. Mater. Sci. Eng. B 2010, 167, 43-50. [CrossRef]

15. Cheng, J.; He, G.; Zhang, F. A mini-review on anion exchange membranes for fuel cell applications: Stability issue and addressing strategies. Int. J. Hydrogen Energy 2015, 40, 7348-7360. [CrossRef]

16. Bauer, B.; Strathmann, H.; Effenberger, F. Anion-exchange membranes with improved alkaline stability. Desalination 1990, 79, 125-144. [CrossRef]

17. Kim, D.S.; Labouriau, A.; Guiver, M.D.; Kim, Y.S. Guanidinium functionalized anion exchange polymer electrolytes via activated fluorophenyl amine reaction. Chem. Mater. 2011, 23, 3795-3797. [CrossRef]

18. Hou, H.Y.; Sun, G.Q.; He, R.H.; Sun, B.; Jin, W.; Liu, H.; Xin, Q. Alkali doped polybenzimidazole membrane for alkaline direct methanol fuel cell. Int. J. Hydrogen Energy 2008, 33, 7172-7176. [CrossRef]

19. Rao, A.H.N.; Kim, H.J.; Nam, S.; Kim, T.H. Cardo poly(arylene ether sulfone) block copolymers with pendant imidazolium side chains as novel anion exchange membranes for direct methanol alkaline fuel cell. Polymer 2013, 54, 6918-6928. [CrossRef] 
20. Deavin, O.I.; Murphy, S.; Ong, A.L.; Poynton, S.D.; Zeng, R.; Herman, H.; Varcoe, J.R. Anion-exchange membranes for alkaline polymer electrolyte fuel cells: Comparison of pendent benzyltrimethylammoniumand benzylmethylimidazolium-head-groups. Energy Environ. Sci. 2012, 5, 8584-8597. [CrossRef]

21. Wang, J.; Wei, H.; Yang, S.; Fang, H.; Xu, P.; Ding, Y. Constructing pendent imidazolium-based poly(phenylene oxide)s for anion exchange membranes using a click reaction. RSC Advance 2015, 5, 93415-93422. [CrossRef]

22. Clark, T.J.; Robertson, N.J.; Kostalik, I.V.H.A.; Lobkovsky, E.B.; Mutolo, P.F.; Abruna, H.C.D.; Coates, G.W. A ring-opening metathesis polymerization route to alkaline anion exchange membranes: Development of hydroxide-conducting thin films from an ammonium-functionalized monomer. J. Am. Chem. Soc. 2009, 131, 12888-12889. [CrossRef] [PubMed]

23. Fujimoto, C.H.; Hickner, M.A.; Cornelius, C.J.; Loy, D.A. Ionomeric poly(phenylene) prepared by Diels-Alder polymerization: Synthesis and physical properties of a novel polyelectrolyte. Macromolecules 2005, 38, 5010-5016. [CrossRef]

24. Lim, Y.D.; Lee, H.C.; Lee, S.H.; Jang, H.H.; Hossain, M.A.; Cho, Y.G.; Kim, T.H.; Hong, Y.T.; Kim, W.G. Synthesis and properties of sulfonated poly(phenylene sulfone)s without ether linkage by Diels-Alder reaction for PEMFC application. Electrochimica Acta 2014, 119, 16-23. [CrossRef]

25. Ghassemi, H.; McGrath, J.E. Synthesis and properties of new sulfonated poly( $p$-phenylene) derivatives for proton exchange membranes. I. Polymer 2004, 45, 5847-5854. [CrossRef]

26. Jang, H.H.; Hong, T.H.; Yoo, J.H.; Lee, S.H.; Pyo, J.S.; Sutradhar, S.C.; Ju, H.C.; Kim, W.G. Preparation and characterization of sulfonated poly(phenylene)s membranes containing conjugated moiety via nickel catalyzed carbon-carbon coupling polymerization. Int. J. Hydrogen Energy 2015, 40, 14364-14370. [CrossRef]

27. Guzmman-Gutierrez, T.M.; Daniel, R.N.; Serguei, F.; Salvador, L.M.; Mikhail, G.Z.; Carmen, G.M.; Hernandez, M.; Kricheldorf, H.; Edward, S.W. Dramatic enhancement of superacid-catalyzed polyhydroxyalkylation reactions. Macromolecules 2011, 44, 194-202. [CrossRef]

28. Lee, S.H.; Lim, Y.D.; Hossain, M.A.; Jang, H.H.; Jeon, Y.T.; Lee, S.Y.; Jin, L.; Kim, W.G. Synthesis and properties of grafting sulfonated polymer containing isatin by super acid-catalyzed polyhydroxyalkylation reaction for PEMFC. Renewable Energy 2015, 79, 72-77.

29. Lim, Y.D.; Seo, D.W.; Lee, S.H.; Ju, H.H.; Hong, T.W.; Kim, D.M.; Ju, H.C.; Kim, W.G. Synthesis and properties of cis/trans mixtures of bis(4-hydroxyphenyl)-1,2-diphenylethylene containing sulfonated poly(ethersulfone)s proton exchange membranes. Int. J. Hydrogen Energy 2013, 38, 7667-7673.

30. Fu, H.; Yun, H.; Kwei, T.K.; Okamoto, Y.; Blumstengel, S.; Walser, A.; Dorsinville, R. Blue Photo- and Electroluminescence Based on Poly(2-benzoyl-1,4-phenylene) and Poly(2,5-dibenzoyl-1,4-phenylene. Polym. Adv. Technol. 1999, 10, 259-264.

31. Seo, D.W.; Sarker, S.; Nath, N.C.D.; Choi, S.W.; Ahammad, A.J.S.; Lee, J.J.; Kim, W.G. Synthesis of a novel imidazolium-based electrolytes and application for dye-sensitized solar cells. Electrochim. Acta 2010, 55, 1483-1488.

32. Basuli, U.; Jose, J.; Lee, R.H.; Yoo, Y.H.; Jeong, K.U.; Ahn, J.H.; Nah, C.W. Properties and Degradation of the Gasket Component of a Proton Exchange Membrane Fuel Cell-A Review. J. Nanosci. Nanotechnol. 2012, 12, $7641-7657$.

33. Gou, M.; Fang, J.; Xu, H.; Li, W.; Lu, X.; Lan, C.; Li, K. Synthesis and characterization of novel anion exchange membranes based on imidazolium-type ionic liquid for alkaline fuel cells. J. Memb. Sci. 2010, 362, 97-104.

34. Henkensmeier, D.; Cho, H.; Brela, M.; Michalak, A.; Dyck, A.; Germer, W.; Duong, N.M.H.; Jang, J.H.; Kim, H.J.; Woo, N.S.; Lim, T.H. Anion conducting polymers based on ether linked polybenzimidazole (PBI-OO). Int. J. Hydrogen Energy 2014, 39, 2842-2853.

35. Yanagi, H.; Fukuta, K. Anion Exchange Membrane and Ionomer for Alkaline Membrane Fuel Cells (AMFCs). ECS Transactions 2008, 16, 257-262.

36. Wang, J.; Zhao, Z.; Gong, F.; Li, S.; Zhang, S. Synthesis of soluble poly(arylene ether sulfone) ionomers with pendant quaternary ammonium groups for anion exchange membranes. Macromolecules 2009, 42, 8711-8717.

37. Price, S.C.; Williams, K.S.; Beyer, F.L. Relationships between structure and alkaline stability of imidazolium cations for fuel cell membrane applications. ACS Macro Lett. 2014, 3, 160-165.

(C) 2016 by the authors; licensee MDPI, Basel, Switzerland. This article is an open access article distributed under the terms and conditions of the Creative Commons by Attribution (CC-BY) license (http:/ / creativecommons.org/licenses/by/4.0/). 